\title{
Co-occurrence of free-living protozoa and foodborne pathogens on dishcloths: Implications for food safety
}

\author{
N. Chavatte ${ }^{\text {a }}$, J. Baré ${ }^{\text {a }}$, E. Lambrecht ${ }^{\text {a }}$ I. Van Damme ${ }^{\text {a }}$, M. Vaerewijck ${ }^{\text {a }}$, K. Sabbe ${ }^{\text {b }}$, K. Houf ${ }^{\text {a,* }}$ \\ a Department of Veterinary Public Health and Food Safety, Faculty of Veterinary Medicine, Ghent University, Salisburylaan 133, 9820 Merelbeke, Belgium \\ b Department of Biology, Faculty of Sciences, Ghent University, Krijgslaan 281, 9000 Ghent, Belgium
}

\section{A R T I C L E I N F O}

\section{Article history:}

Received 27 June 2014

Received in revised form 21 August 2014

Accepted 24 August 2014

Available online 16 September 2014

\section{Keywords:}

Free-living protozoa (FLP)

Foodborne pathogens

Dishcloths

Enumeration

Diversity

Most Probable Number (MPN)

\begin{abstract}
A B S T R A C T
In the present study, the occurrence of free-living protozoa (FLP) and foodborne bacterial pathogens on dishcloths was investigated. Dishcloths form a potentially important source of cross-contamination with FLP and foodborne pathogens in food-related environments. First various protocols for recovering and quantifying FLP from dishcloths were assessed. The stomacher technique is recommended to recover flagellates and amoebae from dishcloths. Ciliates, however, were more efficiently recovered using centrifugation. For enumeration of freeliving protozoa on dishcloths, the Most Probable Number method is a convenient method. Enrichment was used to assess FLP diversity on dishcloths $(n=38)$. FLP were found on $89 \%$ of the examined dishcloths; $100 \%$ of these tested positive for amoebae, $71 \%$ for flagellates and $47 \%$ for ciliates. Diversity was dominated by amoebae: vahlkampfiids, vannellids, Acanthamoeba spp., Hyperamoeba sp. and Vermamoeba vermiformis were most common. The ciliate genus Colpoda was especially abundant on dishcloths while heterotrophic nanoflagellates mainly belonged to the genus Bodo, the glissomonads and cercomonads. The total number of FLP in used dishcloths ranged from 10 to $10^{4} \mathrm{MPN} / \mathrm{cm}^{2}$. Flagellates were the most abundant group, and ciliates the least abundant. Detergent use was identified as a prime determinant of FLP concentrations on used dishcloths. Bacterial load on dishcloths was high, with a mean total of aerobic bacteria of $7.47 \log _{10} \mathrm{cfu} / \mathrm{cm}^{2}$. Escherichia coli was detected in $68 \%(26 / 38)$ of the used dishcloths, with concentrations up to $4 \log _{10} \mathrm{cfu} / \mathrm{cm}^{2}$. Foodborne pathogens including Staphylococcus aureus (19/38), Arcobacter butzleri (5/38) and Salmonella enterica subsp. enterica ser. Halle $(1 / 38)$ were also present. This study showed for the first time that FLP, including some opportunistic pathogens, are a common and diverse group on dishcloths. Moreover, important foodborne pathogens are also regularly recovered. This simultaneous occurrence makes dishcloths a potential risk factor for cross-contamination and a microbial niche for bacteria-FLP interactions.
\end{abstract}

(C) 2014 Elsevier B.V. All rights reserved.

\section{Introduction}

Free-living protozoa (FLP) are unicellular heterotrophic eukaryotic organisms with a widespread distribution in aquatic (freshwater and marine) and terrestrial ecosystems (Hausmann et al., 2003). They are also present on food, like vegetables (Gourabathini et al., 2008; Vaerewijck et al., 2011), and in food-related environments, such as broiler houses (Baré et al., 2009, 2011; Snelling et al., 2005), meatcutting plants (Vaerewijck et al., 2008), and domestic refrigerators (Vaerewijck et al., 2010).

Free-living protozoa are important predators of bacteria (Pernthaler, 2005; Sherr and Sherr, 2002). Some bacteria, however, are able to resist

\footnotetext{
* Corresponding author at: Department of Veterinary Public Health and Food Safety, Ghent University, Salisburylaan 133, 9820 Merelbeke, Belgium. Tel.: + 32926474 51; fax: + 3292647491 .

E-mail addresses: natascha.chavatte@ugent.be (N. Chavatte), julie.bare@ugent.be (J. Baré), ellen.lambrecht@ugent.be (E. Lambrecht), inge.vandamme@ugent.be (I. Van Damme), mario.vaerewijck@ugent.be (M. Vaerewijck), koen.sabbe@ugent.be (K. Sabbe), kurt.houf@ugent.be (K. Houf).
}

protozoan grazing, and can survive inside FLP cells. These include various foodborne pathogens such as Campylobacter jejuni (Axelsson-Olsson et al., 2005; Baré et al., 2010), Escherichia coli 0157:H7 (Barker et al., 1999), Listeria monocytogenes (Zhou et al., 2007), Salmonella spp. (Gaze et al., 2003; Tezcan-Merdol et al., 2004), Staphylococcus aureus (Huws et al., 2008), Arcobacter butzleri (Medina et al., 2014) and Yersinia enterocolitica (Lambrecht et al., 2013). However intraprotozoan survival and/or replication depend on various factors such as bacterial strain and environmental conditions (Schuppler, 2014; Vaerewijck et al., 2014). As a result, FLP can act as vectors, introducing pathogens into novel habitats, or as transmission routes toward hosts (Berk et al., 1998; Bouyer et al., 2007; Brandl et al., 2005; Matz and Kjelleberg, 2005; Snelling et al., 2008). In addition, they can also act as a protective niche or shelter for bacteria against harsh environmental conditions (Barker and Brown, 1994; King et al., 1988; Snelling et al., 2005), or even as training grounds and evolutionary cribs for foodborne pathogens (Molmeret et al., 2005), enhancing bacterial virulence and mediating bacterial gene transfer. This points toward a role of FLP in the epidemiology of foodborne pathogenic bacteria with significant implications for food safety and public health 
(Gourabathini et al., 2008; Greub and Raoult, 2004; Thomas et al., 2010; Vaerewijck et al., 2014).

Dishcloths are commonly used to clean surfaces, kitchen equipment and utensils, crockery and cutlery, etc., enhancing the potential for cross-contamination between food-related habitats (Kusumaningrum et al., 2003; Mattick et al., 2003). Foodborne bacteria are also commonly present in kitchens and households (Jackson et al., 2007; Macias-Rodriguez et al., 2013; Scott et al., 2008) and form an important source of foodborne illness (Luber, 2009; Newell et al., 2010). High bacterial concentrations (up to $5 \log _{10} \mathrm{cfu} / \mathrm{ml}$ ) have been reported from dishcloths (Gorman et al., 2002). The moist conditions, presence of food residues, and storage at room temperature favors the survival and even growth of (pathogenic) bacteria, such as Listeria spp., E. coli, Salmonella spp., S. aureus and C. jejuni (Beumer et al., 1996; Gorman et al., 2002; Hilton and Austin, 2000; Josephson et al., 1997).

At present no information on the occurrence of FLP on dishcloths and the simultaneous occurrence of foodborne bacterial pathogens, is available. Furthermore, in contrast to bacteriological analysis, to date no standardized protocols for recovering and quantifying FLP from dishcloths are available.

The aims of the present study therefore were: (a) to develop and evaluate protocols for recovering and quantifying FLP from dishcloths; (b) to assess the occurrence, total number and diversity of FLP in used dishcloths; (c) to detect and enumerate bacteria in dishcloths, with special focus on most common foodborne pathogens; (d) to assess the simultaneous occurrence between foodborne pathogens and freeliving protozoa on dishcloths; (e) to evaluate which factors have an impact on both FLP and bacterial presence and concentrations in used dishcloths.

\section{Material and methods}

2.1. Development and evaluation of two protocols for the recovery and quantification of FLP from dishcloths

In order to develop a protocol for recovering and quantifying FLP from dishcloths, spiking experiments with known concentrations of FLP were performed. Two recovery protocols were tested: (i) the centrifugation protocol which was optimized for the recovery of FLP and (ii) the stomacher protocol which is frequently used for bacteriological analysis (Lee, 2010; Sharma et al., 2009). For quantification of FLP from dishcloths, the Most Probable Number (MPN) method and a direct counting method were evaluated.

\subsubsection{Cultivation of FLP}

Three FLP species, representing the three main protozoan morphogroups, i.e. ciliates, flagellates and amoebae, were selected as model organisms. Tetrahymena pyriformis (CCAP 1630/1W) and Acanthamoeba castellanii (ATCC 30324) were cultivated axenically in $75 \mathrm{~cm}^{2}$ tissue culture flasks (TPP AG, Trasadingen, Switzerland) in proteose peptone yeast extract medium (PPY) (CCAP, Oban, UK, http:// www.ccap.ac.uk) and proteose peptone yeast extract glucose (PYG) (ATCC, http://www.lgcstandards-atcc.org), respectively. Cercomonas sp. was previously isolated from a meat-cutting plant (Vaerewijck et al., 2008) and cultivated non-axenically in $75 \mathrm{~cm}^{2}$ tissue culture flasks in Page's Amoeba Saline (PAS, CCAP recipe), enriched with sterile, uncooked rice grains as a carbon source to stimulate bacterial growth (Patterson, 1998). T. pyriformis and A. castellanii were grown for 4 days at $25{ }^{\circ} \mathrm{C}$ and Cercomonas sp. was grown for 5 days at $25^{\circ} \mathrm{C}$. The protozoan cultures were centrifuged [T. pyriformis at $840 \mathrm{~g}$ for $10 \mathrm{~min}$ (Faulkner et al., 2008); A. castellanii and Cercomonas sp. at $540 \mathrm{~g}$ for 10 min (Vaerewijck et al., 2012)] and the supernatant was removed. The pellet was washed twice in PAS. The initial number of protozoan cells was determined using a Fuchs-Rosenthal counting chamber (Brand, Wertheim, Germany). For A. castellanii, enumeration and viability testing was assessed using the trypan blue exclusion assay
(Gao et al., 1997). T. pyriformis and Cercomonas sp. were counted after fixation with $37 \%$ formaldehyde. The final number of organisms to be used in the spiking experiments was then adjusted to a final concentration of $1 \times 10^{6}$ cells $/ \mathrm{ml}$ for $T$. pyriformis and A. castellanii and $1 \times 10^{4}$ cells/ml for Cercomonas sp.

\subsubsection{Evaluation of the protocols}

The protocols were evaluated by spiking known concentrations of each protozoan morphogroup onto sterile dishcloths. By analogy with bacteriological dishcloth protocols (Koo et al., 2013; Lee, 2010), cotton dishcloths were cut into $6 \mathrm{~cm} \times 6 \mathrm{~cm}$ segments $(\mathrm{n}=30)$, autoclaved at $110^{\circ} \mathrm{C}$ for $20 \mathrm{~min}$ and stored in sterile Petri dishes. Three milliliters of PAS was added to the sterile dishcloths, followed by spiking with $2 \mathrm{ml}$ of the final concentration (see above) of the protozoan cultures. For the centrifugation method, the samples were transferred to a $50 \mathrm{ml}$ test tube containing $20 \mathrm{ml}$ PAS and centrifuged at $540 \mathrm{~g}$ for $5 \mathrm{~min}$. After removal of the dishcloths, the remaining liquid was vortexed for $10 \mathrm{~s}$ and $10 \mathrm{ml}$ was used for enumeration of FLP (see below). For the stomacher method, samples were transferred to a stomacher bag, and homogenized for $2 \mathrm{~min}$ after addition of $20 \mathrm{ml}$ PAS (Lee, 2010; Sharma et al., 2009). The dishcloths were then carefully removed and the homogenate was vortexed for $10 \mathrm{~s}$. Ten milliliters of the homogenate was used for enumeration. Free-living protozoa (T. pyriformis, A. castellanii and Cercomonas sp.) were enumerated in parallel by the Most Probable Number method (MPN; 3-tube test) (Blodgett, 2006; Rønn et al., 1995) and by a direct counting method. Both centrifuged and stomachered suspensions were first vortexed to ensure homogeneity before further enumeration by MPN or direct counts.

For the MPN, suspensions were diluted in TSB/PAS (Tryptic Soy Broth diluted 1:1000 in PAS) to $10^{-5}$ for T. pyriformis and A. castellanii and to $10^{-4}$ for Cercomonas sp. and $1 \mathrm{ml}$ was added in triplicate into 24 well microtiter plates (Rønn et al., 1995; Vaerewijck et al., 2011). Control wells were filled with $1 \mathrm{ml} \mathrm{TSB} / \mathrm{PAS}$ only. The microtiter plates were incubated in the dark at $20 \pm 2{ }^{\circ} \mathrm{C}$. After one week of incubation, the wells were examined microscopically for the presence of organisms (Rønn et al., 1995; Vaerewijck et al., 2010). The MPN was calculated using the US Food, Drug and Administration manual and tables (Blodgett, 2006), based on the following equation:

$\sum_{j-1}^{k} \frac{g_{j} m_{j}}{1-\exp \left(-\lambda m_{j}\right)}=\sum_{j-1}^{k} t_{j} m_{j}$

where $\exp (\mathrm{x})$ means $e^{x}$,

$\lambda \quad$ is the concentration,

$k$ denotes the number of dilutions,

$g_{j} \quad$ denotes the number of positive (or growth) tubes in the $j$ th dilution,

$m_{j} \quad$ denotes the amount of the original sample put in each tube in the $j$ th dilution,

$t_{j} \quad$ denotes the number of tubes in the $j$ th dilution.

For direct counting, after fixation of the homogenate with 37\% formaldehyde, $1 \mathrm{ml}$ was transferred to a Sedgewick-Rafter counting chamber (Pyser-SGI Ltd., Kent, UK) and protozoan cells were counted using an Olympus CX41 microscope.

All experiments were performed in duplicate over time.

\subsection{Occurrence, enumeration and diversity of FLP in used dishcloths}

Based on results (see Section 3.1) obtained from the spiking experiments, both recovery methods (centrifugation and stomacher) were applied to retrieve FLP from used dishcloths. For quantification of FLP from used dishcloths, only the MPN-method was applied. Direct 
counting was excluded as after fixation of the sample, it was not possible to differentiate all three protozoan groups (data not shown).

Used dishcloths $(\mathrm{n}=38)$ were collected from unrelated households (colleagues, staff, neighbors, friends, ...), stored in sterile bags and processed the same day. Each dishcloth was cut into 4 segments (approx. $15 \mathrm{~cm} \times 15 \mathrm{~cm}$ ). New, unused dishcloths (bought in sealed plastic bags) were included as controls.

One segment of the used and control dishcloths was processed with the centrifugation protocol in combination with the MPN method. The second segment, diagonally opposed of the first segment, was utilized for the stomacher protocol in combination with the MPN method. Both methodologies were applied as described above. After three to four days and after one week, the wells were examined for presence of FLP, which were then further identified (see below).

A third dishcloth piece was applied for the morphological identification of FLP by an enrichment procedure. Therefore, the dishcloth pieces were transferred to a Petri dish ( $\varnothing 14 \mathrm{~cm}$ ) containing $75 \mathrm{ml}$ PAS. These Petri dishes were incubated in the dark at $20 \pm 2{ }^{\circ} \mathrm{C}$ for enrichment. Autoclaved dry rice grains were added to stimulate bacterial growth (Patterson, 1998). The enrichment cultures were examined after three to four days and after one week (see below).

The fourth segment of the used and control dishcloths was used for bacteriological analysis (see below). Further, a questionnaire was filled in to collect qualitative information on factors which may influence FLP numbers on the dishcloths: fabric type, number of days in use, usage for washing dishes or not, water and detergent usage and absence/presence of pets in the kitchen environment.

Free-living protozoa detected in the MPN (dishcloth segments one and two) or enrichment (segment three) cultures were identified on the basis of morphology and locomotion by light microscopy using standard taxonomic identification sources (Foissner and Berger, 1996; Jeuck and Arndt, 2013; Lee et al., 2005; Page, 1988; Patterson, 1998; Siemersma, 1989; Smirnov and Brown, 2004; Smirnov and Goodkov, 1999; Visvesvara and Schuster, 2008a,b). Organisms were identified to the genus or species level where possible. All taxa were classified according to the recent eukaryote classification of Adl et al. (2012). Organisms that were not assignable to a known species or genus were assigned to a morphogroup (ciliate, flagellate or amoeba).

\subsection{Bacteriological analysis of used dishcloths}

The fourth segment of the used and control dishcloths was used for bacteriological analysis. Each dishcloth piece was analyzed for the presence of the pathogenic bacteria: Campylobacter spp., E. coli, L. monocytogenes, Salmonella spp., S. aureus and Y. enterocolitica using normalized protocols and Arcobacter spp. based on Houf et al. (2001). In parallel, total aerobic bacteria (TAB) counts were performed. Each dishcloth piece was transferred to a stomacher bag and buffered peptone water was added to a final weight of $75 \mathrm{~g}$ to obtain a ratio of $1 \mathrm{ml} \sim 3 \mathrm{~cm}^{2}$. The samples were homogenized for $2 \mathrm{~min}$. Subsamples of the homogenate were used for detection (direct plating and enrichment), and enumeration (direct plating) of (pathogenic) bacteria. Suspected Salmonella colonies were biochemically (API test) and serologically identified, while suspected Arcobacter colonies were identified by multiplex PCR (Douidah et al., 2010) and characterized by ERIC-PCR (Houf et al., 2002).

\subsection{Data analysis}

For quantitative analyses, all FLP and bacterial concentrations were expressed as MPN $/ \mathrm{cm}^{2}$ and $\mathrm{cfu} / \mathrm{cm}^{2}$, respectively. Bacterial concentrations were $\log _{10}(\mathrm{x}+1)$ transformed before further analyses. Data from samples below the limit of quantification (LOQ) were set to one-half of the enumeration threshold. Samples below the protozoan LOQ ( $0.075 \mathrm{MPN} / \mathrm{cm}^{2}$ with the MPN methodology) were set to $0.04 \mathrm{MPN} / \mathrm{cm}^{2}$, while samples below the bacterial LOQ $\left(0.33 \mathrm{cfu} / \mathrm{cm}^{2}\right)$ were set to $0.17 \mathrm{cfu} / \mathrm{cm}^{2}$. For samples above the upper FLP LOQ $\left(>6000 \mathrm{MPN} / \mathrm{cm}^{2}\right)$, the highest MPN count $\left(6000 \mathrm{MPN} / \mathrm{cm}^{2}\right)$ was used. Enrichment and MPN cultures were considered FLP-positive if at least one viable protozoon was observed on at least one time point.

All statistical analyses were carried out using the statistical software package Stata/MP 12.1 (StataCorp, 2011).

The spiking experiments were performed in duplicate over time. Per condition, i.e. combination of recovery and quantification methods, three technical replicates were performed. To evaluate the effect of the recovery (centrifugation vs. stomacher) and quantification (MPN vs. direct counting) methodology for FLP from spiked dishcloths, negative binomial regression analyses were performed per morphogroup.

To evaluate the effect of dishcloth usage and kitchen practices on the total FLP concentration in the used dishcloths, negative binomial regressions were performed. To evaluate the effect of the total aerobic bacteria counts on the presence/absence of each FLP morphogroup in the used dishcloths, logistic regressions were executed.

In order to analyze patterns in FLP species composition (presence/ absence of FLP species) and FLP numbers $(\log (x+1)$ transformed total numbers of ciliates, flagellates and amoebae) in relation to bacterial (TAB counts and presence/absence of pathogens) and environmental data (see Section 2.2), multivariate (ordination) analyses were performed using the program CANOCO for Windows, version 4.5 (ter Braak and Smilauer, 1998). As a preliminary detrended correspondence analysis (DCA) suggested that the underlying response patterns in the FLP species composition dataset were unimodal (length of gradient $>4$, Jongman et al., 1995). Canonical correspondence analysis (CCA) was used to investigate the relationship between the FLP data and the bacteriological and environmental data. As for the FLP numbers dataset the responses were linear (length of gradient $<2$ ), redundancy analysis was used. Forward selection with Monte Carlo permutation testing was used to select the minimal set of bacteriological and environmental variables that contributed significantly and independently to explaining the variation in both FLP datasets (ter Braak and Smilauer, 1998).

\section{Results}

3.1. Development and evaluation of two protocols for the recovery and quantification of FLP from dishcloths

The three model organisms were recovered from dishcloths by two methods (centrifugation and stomacher) and quantified using two enumeration methods (MPN-method and direct counting). The initial numbers of organisms spiked per dishcloth segment were $2 \times 10^{6}$ cells for T. pyriformis and $A$. castellanii and $2 \times 10^{4}$ cells for Cercomonas sp. Both recovery methods showed a reduction in protozoan cells (Table 1 ). The recovery rate varied depending on the methods used and test organism. A statistically significant difference in total number of recovered organisms between both recovery methods was found for both T. pyriformis and A. castellanii. T. pyriformis was recovered in significantly

\section{Table 1}

Mean number \pm standard error of the mean of protozoan organisms $/ \mathrm{cm}^{2}$ per recovery method (centrifugation, stomacher) and quantification method (mean probable number - MPN, direct counting - DC)

\begin{tabular}{|c|c|c|c|c|}
\hline \multirow[t]{2}{*}{ Organism } & \multicolumn{2}{|l|}{ Centrifugation } & \multicolumn{2}{|l|}{ Stomacher } \\
\hline & MPN & DC & MPN & DC \\
\hline $\begin{array}{l}\text { Tetrahymena } \\
\text { pyriformis }\end{array}$ & $4722( \pm 1736)$ & $2997( \pm 475)$ & $917( \pm 750)$ & $542( \pm 124)$ \\
\hline $\begin{array}{l}\text { Acanthamoeba } \\
\text { castellanii }\end{array}$ & $65( \pm 0)$ & $439( \pm 152)$ & $286( \pm 221)$ & $1316( \pm 89)$ \\
\hline Cercomonas sp. & $473( \pm 174)$ & $403( \pm 55)$ & $1157( \pm 511)$ & $497( \pm 156)$ \\
\hline
\end{tabular}

Numbers of spiked organisms were $2 \times 10^{6}$ cells (corresponding to an initial number of $5.5 \times 10^{4}$ cells $/ \mathrm{cm}^{2}$ ) for T. pyriformis and A. castellanii; and $2 \times 10^{4}$ cells (corresponding to an initial number of $5.5 \times 10^{2}$ cells $/ \mathrm{cm}^{2}$ ) for Cercomonas sp. 
higher numbers with the centrifugation method than with the stomacher protocol ( $\mathrm{p}<0.001)$, whereas for A. castellanii, significantly higher numbers were counted after usage of the stomacher method in comparison with the centrifugation protocol $(\mathrm{p}<0.001)$. For the flagellate Cercomonas sp., no statistically significant differences between both recovery protocols were found.

No significant difference between the MPN method and direct counting (Sedgewick-Rafter) was observed for T. pyriformis ( $\mathrm{p}>0.05$ ). Statistically higher numbers of $A$. castellanii were counted by direct counting in comparison to the MPN method ( $p<0.001$ ). The opposite was observed for Cercomonas sp. $(\mathrm{p}<0.05)$.

\subsection{Occurrence, enumeration and diversity of FLP on used dishcloths}

A dishcloth was scored positive for the presence of FLP if ciliates, flagellates or amoebae were observed using either one of the recovery methods (centrifugation, stomacher) or the enrichment procedure. Free-living protozoa were present in $89 \%$ (34/38) of the used dishcloths, with $47 \%$ (16/34) of these testing positive for ciliates and $71 \%(24 / 34)$ for flagellates (Fig. 1). Amoebae were present in 100\% (34/34) of the FLP positive dishcloths. No FLP were detected in the control dishcloths. Almost half (15/34) of the FLP-positive dishcloths contained all three morphogroups. No dishcloths contained only ciliates or flagellates, or the combination of these two groups without amoebae.

After one week, enrichment cultures, performed for FLP identification purposes, revealed more FLP positive dishcloths (33/34) compared to centrifugation (25/34) and stomacher (26/34) recovery methodologies. After enrichment, 16/16 dishcloths were positive for ciliates, while only $6 / 16$ were positive using the centrifugation or stomacher protocols (Fig. 2). For flagellates, 22/24 dishcloths were positive after enrichment, while 12/24 and 16/24 dishcloths were positive using the centrifugation and stomacher method, respectively. The number of dishcloths positive for amoebae was 33/34 after enrichment, 21/34 after centrifugation, and 23/34 after using the stomacher protocol.

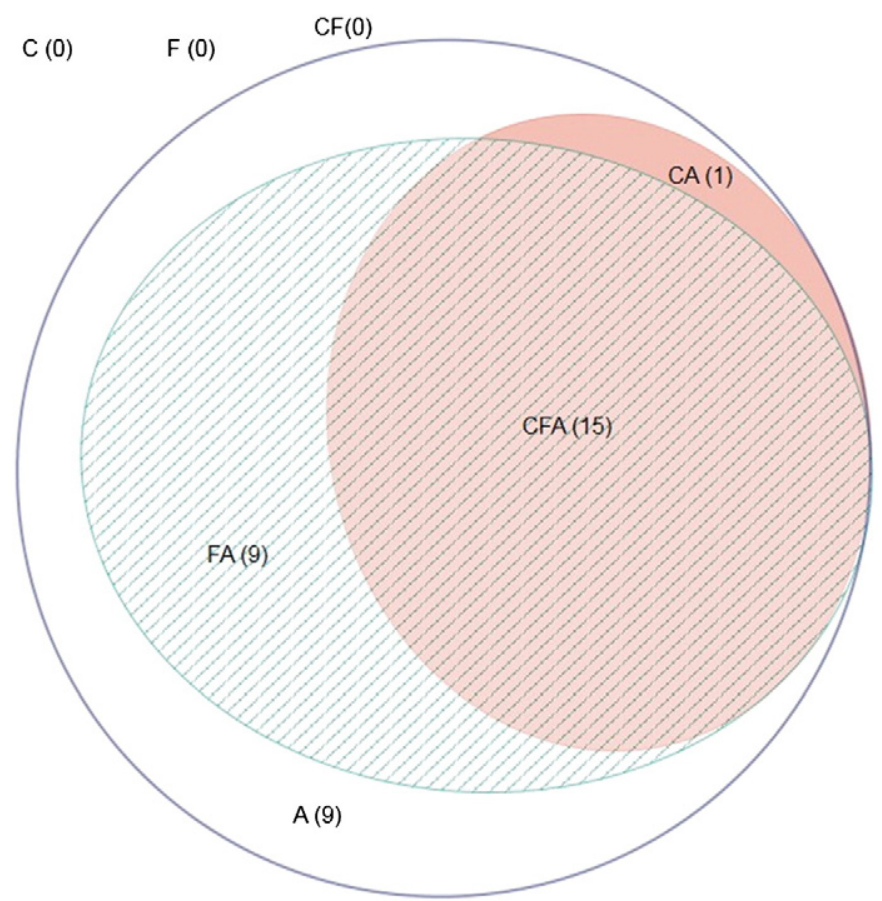

Fig. 1. Distribution of the morphogroups in FLP-positive dishcloths, visualized by a proportional Venn diagram. C, F, and A are representing the presence of ciliates, flagellates and amoebae in dishcloths, respectively. CF, CA and FA are representing the presence of ciliates and flagellates, ciliates and amoebae and flagellates and amoebae in dishcloths, respectively. CFA represents the presence of all three morphogroups (ciliates, flagellates and amoebae) in dishcloths. The number between brackets represents the number of positive dishcloths for that specific morphogroup.

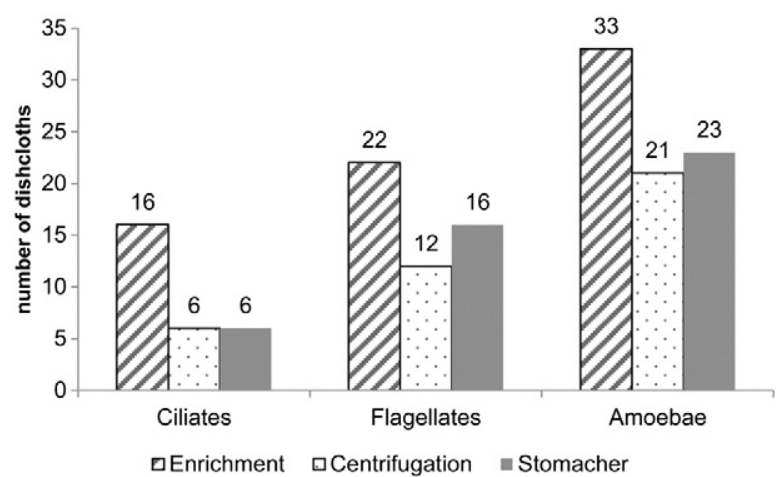

Fig. 2. Number of FLP-positive dishcloths, per morphogroup and methodology.

Numbers of FLP in used dishcloths were estimated using the MPN method. Total FLP numbers and numbers of ciliates, flagellates and amoebae in the used dishcloths were highly variable. Estimated total FLP numbers ranged from 0.11 to $8750 \mathrm{MPN} / \mathrm{cm}^{2}$ and 0.11 to $6108 \mathrm{MPN} / \mathrm{cm}^{2}$ for the centrifugation and stomacher protocols, respectively. In 26\% (centrifugation) and $29 \%$ (stomacher) of the examined dishcloths the estimated total FLP numbers ranged from 10 to $10^{4} \mathrm{MPN} / \mathrm{cm}^{2}$.

Flagellates were the most abundant group (Table 2) with mean numbers of $469 \mathrm{MPN} / \mathrm{cm}^{2}$ (centrifugation) and $373 \mathrm{MPN} / \mathrm{cm}^{2}$ (stomacher). Amoebae were recovered in higher numbers by the stomacher protocol compared to the centrifugation method (mean numbers 382 and $158 \mathrm{MPN} / \mathrm{cm}^{2}$, respectively). The lowest numbers were recorded for ciliates, with $182 \mathrm{MPN} / \mathrm{cm}^{2}$ for the centrifugation method and $5 \mathrm{MPN} / \mathrm{cm}^{2}$ for the stomacher method.

In total 88 FLP ( 8 ciliates, 31 flagellates, 49 amoebae) were identified to genus or species level (Fig. 3). Centramoebida (e.g. Acanthamoeba) and Vannellida (e.g. Vannella) were frequently observed members of the Discosea. Together with Hartmannella and Vermamoeba vermiformis (Tubulinea), they were the most common Amoebozoa. Euglenozoa (e.g. Bodo) and Heterolobosea (e.g. vahlkampfiids) were representatives of the Discoba group. Ciliates all belonged to the Intramacronucleata (Alveolata), with Colpoda being the most often encountered genus. The flagellate groups glissomonads and cercomonads (Rhizaria) were general inhabitants of used dishcloths. Hyperamoeba sp. was present in 16 out of 34 amoebae-positive dishcloths. In addition to FLP, nematodes, rotifers, fungi, yeasts and molds were also detected in some dishcloths.

\subsection{Bacteriological analysis of used dishcloths}

All dishcloths were heavily contaminated with bacteria, with total aerobic bacteria (TAB) counts ranging from 4.36 to $8.93 \log _{10} \mathrm{cfu} / \mathrm{cm}^{2}$, with a mean of $7.47 \pm 0.15 \log _{10} \mathrm{cfu} / \mathrm{cm}^{2}$ (Fig. 4). Escherichia coli was found in 23 dishcloths, with concentrations ranging from 0.12 to $4.25 \log _{10} \mathrm{cfu} / \mathrm{cm}^{2}$ (mean: $1.75 \pm 0.26 \log _{10} \mathrm{cfu} / \mathrm{cm}^{2}$ ).

Foodborne bacterial pathogens were detected in 22 dishcloths. From the four FLP-negative dishcloths, two also tested negative for foodborne

Table 2

Minimum, maximum, mean and standard error of the mean for each morphogroup and method; values are expressed as MPN/ $\mathrm{cm}^{2}$.

\begin{tabular}{lllcr}
\hline$(\mathrm{n}=34)$ & Minimum & Maximum & Mean & Standard error \\
\hline Centrifugation & & & & \\
Ciliates & 0.04 & 6000 & 182 & 176 \\
Flagellates & 0.04 & 6000 & 469 & 256 \\
Amoebae & 0.04 & 2750 & 158 & 89 \\
& & & & \\
Stomacher & & 108 & 5 & 3 \\
Ciliates & 0.04 & 6000 & 373 & 206 \\
Flagellates & 0.04 & 6000 & 382 & 245 \\
Amoebae & 0.04 & & & \\
\hline
\end{tabular}




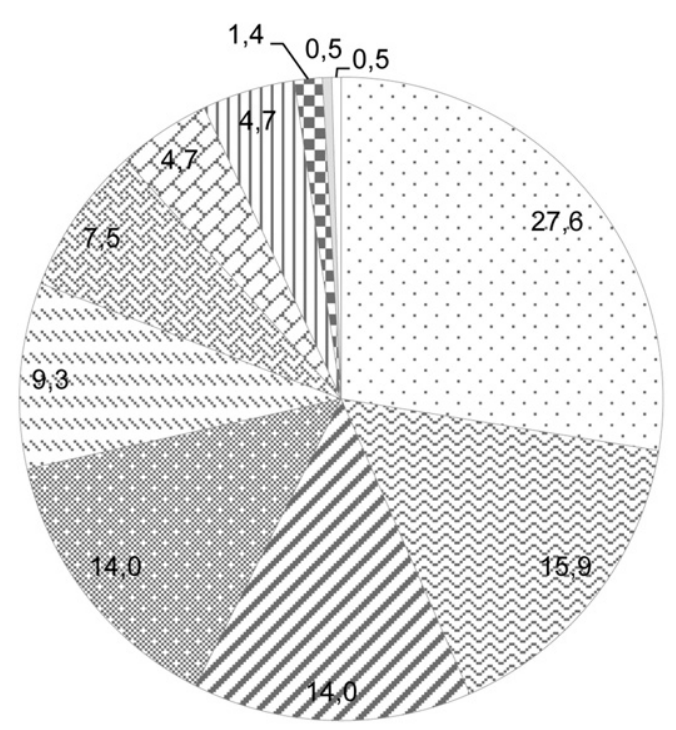

Discosea

$\triangle$ Discoba

Alveolata

Tubulinea

Rhizaria

¿ Hyperamoeba $s p$.

$\checkmark$ Amoebae with unknown affinity

$\square$ Flagellates with unknown affinity

Stramenopiles

Ciliates with unknown affinity

Gracilipodida

Fig. 3. Relative proportion (\%) of FLP taxonomic groups at first rank level, as described by Adl et al. (2012).

pathogens. Staphylococcus aureus ( $\mathrm{n}=19$ positive dishcloths) were recovered in concentrations ranging from 0.12 to $3.48 \log _{10} \mathrm{cfu} / \mathrm{cm}^{2}$ (mean: $\left.0.93 \pm 0.24 \log _{10} \mathrm{cfu} / \mathrm{cm}^{2}\right)$. Salmonella sp. $(\mathrm{n}=1)$ and Arcobacter sp. $(\mathrm{n}=5)$ were recovered from the collected dishcloths after enrichment. Salmonella colonies were biochemically and serologically confirmed as Salmonella enterica subsp. enterica ser. Halle. Arcobacter sp. was identified as Arcobacter butzleri. The five recovered Arcobacter isolates were all further characterized by ERIC-PCR as different strains. Campylobacter spp., Listeria monocytogenes and Yersinia enterocolitica were not detected in the examined dishcloths. No foodborne pathogens were present in the control dishcloths.

\subsection{Evaluation of dishcloth usage and kitchen practices}

All FLP-positive dishcloths harbored TAB. With increasing numbers of TAB, the possibility to find amoebae in the dishcloth increased significantly ( $p=0.023$ ), which was not the case for ciliates and flagellates. No significant differences in the total number of FLP were found between different fabric types, number of days in use, whether the dishcloths were also used to wash the dishes and whether there were pets in the kitchen environment allowed or not $(p>0.05)$. A negative relation was observed between detergent usage and the numbers of

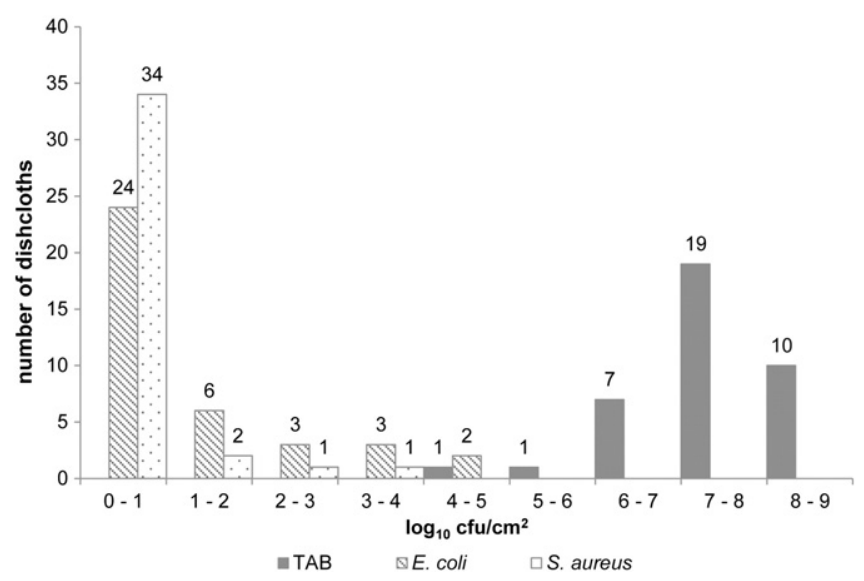

Fig. 4. Bacterial load of dishcloths: total aerobic bacteria (TAB) and concentrations of $E$. coli and S. aureus. TAB: total aerobic bacteria (gray); Escherichia coli (hatched) and Staphylococcus aureus (dotted). ciliates and amoebae $(\mathrm{p} \leq 0.003)$ and TAB counts on dishcloths $(\mathrm{p}<0.025)$. No significant effect was found between detergent usage and the number of flagellates on dishcloths $(\mathrm{p}>0.05)$. The above results were confirmed by the direct ordination analyses (CCA and RDA respectively for FLP species presence/absence and morphogroup numbers) (data not shown). No significant relationships were found between variation in FLP community structure and the measured bacteriological and environmental factors. In contrast, variation in ciliate, flagellate and amoeba numbers were strongly negatively related to detergent use, while a weak but not significant $(\mathrm{p}=0.08$ ) positive elationship existed with the number of days a dishcloth had been in use.

\section{Discussion}

The present study aimed to assess for the first time the occurrence, abundance and diversity of FLP in dishcloths in relation to bacteriological (TAB count, presence and abundance of bacterial foodborne pathogens) and environmental factors (e.g. number of days the dishcloths had been in use and use of detergent). In addition, protocols for recovering and quantifying FLP from dishcloths were developed and evaluated. This study showed that FLP, including some opportunistic pathogens, are a common and diverse microbial group on dishcloths. Important bacterial foodborne pathogens, such as S. aureus, A. butzleri and Salmonella were recovered from dishcloths.

Flagellates were recovered more efficiently than ciliates or amoebae. The lower recovery of amoebae may be ascribed to the high attachment capacity of amoebae. To obtain the total number of FLP (ciliates, flagellates and amoebae), the stomacher protocol in combination with the MPN method is recommended. The stomacher protocol is a broadly used and standardized method (Wu et al., 2003). However when focusing on ciliates in particular, centrifugation and stomacher protocols should be applied in parallel. For enumeration of free-living protozoa on dishcloths, the Most Probable Number method is a convenient method to estimate numbers of FLP as it is particularly useful for low concentrations of organisms (Blodgett, 2006).

Free-living protozoa form common and diverse communities on dishcloths (89\% of the dishcloths FLP-positive). Amoebae were present in all FLP positive dishcloths, whereas ciliates and flagellates never occurred without amoebae. Flagellates were the most abundant group, which is in agreement with the studies of Vaerewijck et al. (2011) and Gourabathini et al. (2008) of FLP on food. The lowest numbers were 
counted for ciliates. Vaerewijck et al. (2011) also observed that ciliates were the least abundant group on butterhead lettuce.

The present study suggests that the use of detergent causes a significant reduction in numbers of ciliates, amoebae and TAB on dishcloths. Azizullah et al. (2011) tested the influence of detergent on motility, swimming velocity and cell shape of the freshwater flagellate Euglena gracilis. A strong impairment effect was seen immediately upon exposure to detergent, but with increasing exposure time, this effect decreased, suggesting acclimatization to these stress conditions. Esteban and Tellez (1992) observed that ciliate numbers in wastewater treatment plants diminished with increasing detergent concentrations. However, further research is needed to assess the direct effect of detergent usage on the FLP and bacterial communities present in household dishcloths.

Most FLP species were detected after a few days of enrichment, suggesting they were present either in very low numbers of metabolically active cells or as resting stages (cysts) (Corliss, 2001). Free-living protozoa on dishcloths are frequently exposed to stress conditions such as desiccation, disinfection and cleaning treatments. Through cyst formation, various protozoan species can survive unfavorable conditions (Aksozek et al., 2002; Coulon et al., 2010; Dupuy et al., 2014; Sriram et al., 2008) which may also be the case on dishcloths.

The diversity of FLP in used dishcloths was the highest within the amoebae group, revealing the dominance of vahlkampfiids, vannellids, Acanthamoeba spp., Hyperamoeba sp. and Vermamoeba vermiformis.

Hyperamoeba sp. were present in almost half of the amoebae positive dishcloths. This species, being closely related to the myxogastric slime molds (Walker et al., 2003; Walochnik et al., 2004), has been isolated from human feces, pond water and fecally contaminated soil (Karpov and Mylnikov, 1997; Zaman et al., 1999). This amoeba has three life cycle stages: a flagellated stage, an amoeboid trophozoite and a cyst stage. Zaman et al. (1999) confirmed the presence of bacteria in the ectocyst of Hyperamoeba by using electron microscopy, which leads back to the possible role of FLP as vector and reservoir of foodborne bacteria. To date, Hyperamoeba sp. has never been observed in food-related environments.

In all ciliate positive dishcloths, Colpoda spp. (Colpoda steinii most common) were observed, making Colpoda a typical ciliate on dishcloths. Colpoda spp. are common and widely distributed terrestrial ciliates (Foissner, 1993) and are also able to form cysts to survive unfavorable conditions such as desiccation (Maeda et al., 2005). Colpoda steinii has also been recovered from spinach (Gourabathini et al., 2008).

Heterotrophic nanoflagellates were mainly Bodo spp., glissomonads and cercomonads. The genus Bodo is a member of the Kinetoplastida (Euglenozoa) and is found worldwide in freshwater and marine habitats.

Except for Hyperamoeba sp., the dominance of above mentioned protozoan species is somewhat similar to common taxa present in other food-related environments such as broiler houses (Baré et al., 2009), meat-cutting plants (Vaerewijck et al., 2008), and domestic refrigerators (Vaerewijck et al., 2010). These species are also detected on vegetables such as mushrooms (Napolitano, 1982), lettuce (Napolitano and Collettieggolt, 1984; Vaerewijck et al., 2011), carrots (Sharma et al., 2004), radishes, tomatoes, cauliflowers and spinach (Rude et al., 1984).

The FLP diversity in used dishcloths is likely an underestimation of the true species richness, as cryptic species, i.e. species that are indistinguishable by morphology alone, were not detected based on this traditional approach (microscopy and culture) (Caron, 2009); and as ciliates and amoebae are often present as cysts (Corliss, 2001). Molecular based techniques like 18S rRNA gene sequencing may overcome this issue although molecular techniques have also their limitation (Forney et al., 2004; Nocker et al., 2007).

Moreover there is always a reduction in recovered cells, as shown in the spiking experiments. As a consequence the total number of FLP on used dishcloths is inevitably an underestimation of the real situation.
Detection and enumeration of bacterial load in dishcloths in combination with seven important foodborne pathogens has not been performed before. Published data, specifically about foodborne bacterial pathogens are also scarce, and mainly relate to spiking experiments (Bae et al., 2012; Diab-Elschahawi et al., 2010; Lee, 2010) and investigations into the occurrence of Salmonella, Campylobacter, E. coli and S. aureus in used dishcloths (Carrasco et al., 2008; Gorman et al., 2002; Hilton and Austin, 2000; Scott et al., 2008). Dishcloths examined in the present study were heavily contaminated. Similar results were also reported by Carrasco et al. (2008) who observed that used dishcloths carry the largest load of total coliforms and fecal coliforms compared to other kitchen surfaces.

In the present study, E. coli was frequently detected in used dishcloths, with concentrations up to $4.25 \log _{10} \mathrm{cfu} / \mathrm{cm}^{2}$. E. coli is an indicator organism for hygiene and fecal contamination. Most E. coli are harmless and commensals of the intestinal tract, but some strains are pathogenic and causative agents of foodborne diseases. Washing hands, rinsing vegetables and fruits, and the fact that $E$. coli can survive desiccation for more than $24 \mathrm{~h}$ (Bale et al., 1993; Mattick et al., 2003) can explain its frequent occurrence in kitchen environments and more specific in used dishcloths. Lee (2010) and Bae et al. (2012) showed that after inoculation of cultured cells on commercial available dishcloths E. coli grew very well at room temperature.

Besides direct pathogenic effects toward humans, FLP are also important in the ecology and epidemiology of foodborne bacterial pathogens, as described before. Interactions of E. coli with Acanthamoeba spp. and limax amoebae such as Vermamoeba vermiformis (previously named Hartmannella vermiformis) and Vahlkampfia (all present in the examined dishcloths) have been recorded (Alsam et al., 2006; Barker et al., 1999; Chekabab et al., 2013; Jung et al., 2007; Walochnik et al., 1998).

Staphylococcus aureus is a potential foodborne pathogen producing enterotoxins which can cause gastrointestinal problems after consumption of contaminated food. Milk and dairy products are important contamination sources (Balaban and Rasooly, 2000; Bianchi et al., 2014). In the present study, $50 \%$ (concentrations up to $10^{3} \mathrm{cfu} / \mathrm{cm}^{2}$ ) of the dishcloths harbored $S$. aureus, which is a higher prevalence than recorded by Hilton and Austin (2000) and (Scott et al., 2008). Survival and growth of S. aureus in Acanthamoeba spp. (Anacarso et al., 2012; Cardas et al., 2012; Huws et al., 2006) and H. vermiformis (Pickup et al., 2007), both organisms present on dishcloths, was observed.

Campylobacter spp. were not detected in dishcloths examined in the present study, which is in agreement with other studies (Gorman et al., 2002; Hilton and Austin, 2000).

Arcobacter is an emerging foodborne pathogen (Van den Abeele et al., 2014) which can cause human infections through the consumption of contaminated food such as poultry products, pork and beef (De Smet et al., 2012; Ho et al., 2006; Van Driessche and Houf, 2007). Apart from contaminated meat products, drinking water is also a potential contamination route (Jacob et al., 1993). The present study reports for the first time Arcobacter presence in used dishcloths.

In the present study none of the dishcloths tested positive for pathogenic $L$. monocytogenes. This is in contrast with the study of Beumer et al. (1996), where Listeria was present in 37\% of the dishcloths, of which $45 \%$ was Listeria monocytogenes.

One dishcloth tested positive for Salmonella enterica subsp. enterica ser. Halle. This particular serovar is associated with turtles. As indicated by obtained questionnaire data, the owner of the dishcloth kept turtles as pets.

Free-living protozoa can impact human health in a direct or indirect way. Some FLP organisms found in the present study, like Acanthamoeba spp., Vahlkampfia spp. and V. vermiformis, are classified as opportunistic pathogenic amoebae, causing amoebic keratitis infections (Abedkhojasteh et al., 2013; Niyyati et al., 2010). Further, FLP can indirectly cause infection pressure to human health by sheltering bacteria pathogenic to humans. 
Free-living protozoa are often not incorporated in microbiological studies of food and food-related environments, as a result data of FLP in these environments are scarce. However, FLP are known vectors for (pathogenic) bacteria, and the present study elucidate the simultaneous presence of both FLP and bacteria in dishcloths. Further research on the impact of this finding on bacterial ecology and epidemiology is needed. The present study clearly demonstrates the reducing effect of detergent on both FLP and bacterial numbers, showing the importance of good hygiene measures in kitchen environments.

\section{Acknowledgments}

This work was supported by the Special Research Fund of Ghent University (BOF, Ghent, Belgium; grant 01J07111). Many thanks to M. Boonaert, S. Vangeenberghe and C. Van Lancker for the technical assistance. We thank all volunteers for providing their dishcloths and completing the questionnaire.

\section{References}

Abedkhojasteh, H., Niyyati, M., Rahimi, F., Heidari, M., Farnia, S., Rezaeian, M., 2013. First report of Hartmannella keratitis in a cosmetic soft contact lens wearer in Iran. Iran. J. Parasitol. 8, 481-485.

Adl, S.M., Simpson, A.G.B., Lane, C.E., Lukes, J., Bass, D., Bowser, S.S., Brown, M.W., Burki, F, Dunthorn, M., Hampl, V., Heiss, A., Hoppenrath, M., Lara, E., le Gall, L., Lynn, D.H., McManus, H., Mitchell, E.A.D., Mozley-Stanridge, S.E., Parfrey, L.W., Pawlowski, J., Rueckert, S., Shadwick, L., Schoch, C.L., Smirnov, A., Spiegel, F.W., 2012. The revised classification of eukaryotes. J. Eukaryot. Microbiol. 59, 429-493.

Aksozek, A., McClellan, K., Howard, K., Niederkorn, J.Y., Alizadeh, H., 2002. Resistance of Acanthamoeba castellanii cysts to physical, chemical, and radiological conditions. J. Parasitol. 88, 621-623.

Alsam, S., Jeong, S.R., Sissons, J., Dudley, R., Kim, K.S., Khan, N.A., 2006. Escherichia coli interactions with Acanthamoeba: a symbiosis with environmental and clinical implications. J. Med. Microbiol. 55, 689-694.

Anacarso, I. de Niederhaeusern, S. Messi, P. Guerrieri, E., Iseppi, R., Sabia, C., Bondi, M. 2012. Acanthamoeba polyphaga, a potential environmental vector for the transmission of food-borne and opportunistic pathogens. J. Basic Microbiol. 52, 261-268.

Axelsson-Olsson, D., Waldenstrom, J., Broman, T., Olsen, B., Holmberg, M., 2005. Protozoan Acanthamoeba polyphaga as a potential reservoir for Campylobacter jejuni. Appl. Environ. Microbiol. 71, 987-992.

Azizullah, A., Richter, P., Haeder, D.-P., 2011. Toxicity assessment of a common laundry detergent using the freshwater flagellate Euglena gracilis. Chemosphere 84 $1392-1400$

Bae, Y.M., Lee, S.H., Yoo, J.H., Lee, S.Y., 2012. Survival and growth of foodborne pathogens on commercial dishsponges/cloths and inhibitory effects of sanitizers. Food Sci. Technol. Res. 18, 437-443.

Balaban, N., Rasooly, A., 2000. Staphylococcal enterotoxins. Int. J. Food Microbiol. 61, 1-10.

Bale, M.J., Bennett, P.M., Beringer, J.E., Hinton, M., 1993. The survival of bacteria exposed to desiccation on surfaces associated with farm-buildings. J. Appl. Bacteriol. 75, 519-528.

Baré, J., Sabbe, K., Van Wichelen, J., van Gremberghe, I., D'Hondt, S., Houf, K., 2009. Diversity and habitat specificity of free-living protozoa in commercial poultry houses. Appl. Environ. Microbiol. 75, 1417-1426.

Baré, J., Sabbe, K., Huws, S., Vercauteren, D., Braeckmans, K., van Gremberghe, I., Favoreel, H., Houf, K., 2010. Influence of temperature, oxygen and bacterial strain identity on the association of Campylobacter jejuni with Acanthamoeba castellanii. FEMS Microbiol. Ecol. 74, 371-381.

Baré, J., Houf, K., Verstraete, T., Vaerewijck, M., Sabbe, K., 2011. Persistence of free-living protozoan communities across rearing cycles in commercial poultry houses. Appl. Environ. Microbiol. 77, 1763-1769.

Barker, J., Brown, M.R., 1994. Trojan horses of the microbial world: protozoa and the survival of bacterial pathogens in the environment. Microbiology 140 (Pt 6), 1253-1259.

Barker, J., Humphrey, T.J., Brown, M.W.R., 1999. Survival of Escherichia coli 0157 in a soil protozoan: implications for disease. FEMS Microbiol. Lett. 173, 291-295.

Berk, S.G., Ting, R.S., Turner, G.W., Ashburn, R.J., 1998. Production of respirable vesicles containing live Legionella pneumophila cells by two Acanthamoeba spp. Appl. Environ. Microbiol. 64, 279-286.

Beumer, R.R., te Giffel, M.C., Spoorenberg, E., Rombouts, F.M., 1996. Listeria species in domestic environments. Epidemiol. Infect. 117, 437-442.

Bianchi, D.M., Gallina, S., Bellio, A., Chiesa, F., Civera, T., Decastelli, L., 2014. Enterotoxin gene profiles of Staphylococcus aureus isolated from milk and dairy products in Italy. Lett. Appl. Microbiol. 58, 190-196.

Blodgett, R., 2006. US Food and Drug Administration Online Bacteriological Analytical Manual Appendix 2: Most Probable Number from Serial Dilutions.

Bouyer, S., Imbert, C., Rodier, M.H., Hechard, Y., 2007. Long-term survival of Legionella pneumophila associated with Acanthamoeba castellanii vesicles. Environ. Microbiol. 9, 1341-1344.
Brandl, M.T., Rosenthal, B.M., Haxo, A.F., Berk, S.G., 2005. Enhanced survival of Salmonella enterica in vesicles released by a soilborne Tetrahymena species. Appl. Environ. Microbiol. 71, 1562-1569.

Cardas, M., Khan, N.A., Alsam, S., 2012. Staphylococcus aureus exhibit similarities in their interactions with Acanthamoeba and ThP1 macrophage-like cells. Exp. Parasitol. 132, 513-518.

Caron, D.A., 2009. Past president's address: protistan biogeography: why all the fuss? J. Eukaryot. Microbiol. 56, 105-112.

Carrasco, L., Mena, K.D., Mota, L.C., Ortiz, M., Behravesh, C.B., Gibbs, S.G., Bristol, J.R., Mayberry, L., Cardenas, V.M., 2008. Occurrence of faecal contamination in households along the US-Mexico border. Lett. Appl. Microbiol. 46, 682-687.

Chekabab, S.M., Daigle, F., Charette, S.J., Dozois, C.M., Harel, J., 2013. Shiga toxins decrease enterohaemorrhagic Escherichia coli survival within Acanthamoeba castellanii. FEMS Microbiol. Lett. 344, 86-93.

Corliss, J.O., 2001. Protozoan Cysts and Spores, Encyclopedia of Life Sciences. John Wiley \& Sons, pp. $1-8$

Coulon, C., Collignon, A., McDonnell, G., Thomas, V., 2010. Resistance of Acanthamoeba cysts to disinfection treatments used in health care settings. J. Clin. Microbiol. 48, 2689-2697.

De Smet, S., De Zutter, L., Houf, K., 2012. Spatial distribution of the emerging foodborne pathogen Arcobacter in the gastrointestinal tract of pigs. Foodborne Pathog. Dis. 9, 1097-1103.

Diab-Elschahawi, M., Assadian, O., Blacky, A., Stadler, M., Pernicka, E., Berger, J., Resch, H., Koller, W., 2010. Evaluation of the decontamination efficacy of new and reprocessed microfiber cleaning cloth compared with other commonly used cleaning cloths in the hospital. Am. J. Infect. Control 38, 289-292.

Douidah, L., De Zutter, L., Vandamme, P., Houf, K., 2010. Identification of five human and mammal associated Arcobacter species by a novel multiplex-PCR assay. J. Microbiol. Methods 80, 281-286.

Dupuy, M., Berne, F., Herbelin, P., Binet, M., Berthelot, N., Rodier, M.H., Soreau, S., Hechard, Y., 2014. Sensitivity of free-living amoeba trophozoites and cysts to water disinfectants. Int. J. Hyg. Environ. Health 217, 335-339.

Esteban, G., Tellez, C., 1992. The influence of detergents on the development of ciliate communities in activated-sludge. Water Air Soil Pollut. 61, 185-190.

Faulkner, G., Berk, S.G., Garduno, E., Ortiz-Jimenez, M.A., Garduno, R.A., 2008. Passage through Tetrahymena tropicalis triggers a rapid morphological differentiation in Legionella pneumophila. J. Bacteriol. 190, 7728-7738.

Foissner, W., 1993. Colpodea (Ciliophora). Protozoenfauna 4/1, 1-798 (i-x).

Foissner, W., Berger, H., 1996. A user-friendly guide to the ciliates (Protozoa, Ciliophora) commonly used by hydrobiologists as bioindicators in rivers, lakes, and waste waters, with notes on their ecology. Freshw. Biol. 35, 375-482.

Forney, L.J., Zhou, X., Brown, C.J., 2004. Molecular microbial ecology: land of the one-eyed king. Curr. Opin. Microbiol. 7, 210-220.

Gao, L.Y., Harb, O.S., AbuKwaik, Y., 1997. Utilization of similar mechanisms by Legionella pneumophila to parasitize two evolutionarily distant host cells, mammalian macrophages and protozoa. Infect. Immun. 65, 4738-4746.

Gaze, W.H., Burroughs, N., Gallagher, M.P., Wellington, E.M.H., 2003. Interactions between Salmonella typhimurium and Acanthamoeba polyphaga, and observation of a new mode of intracellular growth within contractile vacuoles. Microb. Ecol. 46, 358-369.

Gorman, R., Bloomfield, S., Adley, C.C., 2002. A study of cross-contamination of food-borne pathogens in the domestic kitchen in the Republic of Ireland. Int. J. Food Microbiol. $76,143-150$.

Gourabathini, P., Brandl, M.T., Redding, K.S., Gunderson, J.H., Berk, S.G., 2008. Interactions between food-borne pathogens and protozoa isolated from lettuce and spinach. Appl. Environ. Microbiol. 74, 2518-2525.

Greub, G., Raoult, D., 2004. Microorganisms resistant to free-living amoebae. Clin. Microbiol. Rev. 17, 413-433.

Hausmann, K., Hülsmann, N., Radek, R., 2003. Protistology. Schweizerbart'sche verlagbuchhandlung, Stuttgart, Germany.

Hilton, A.C. Austin, E. 2000. The kitchen dishcloth as a source of and vehicle for foodborne pathogens in a domestic setting. Int. J. Environ. Health Res. 10, 257-261.

Ho, H.T.K., Lipman, L.J.A., Gaastra, W., 2006. Arcobacter, what is known and unknown about a potential foodborne zoonotic agent! Vet. Microbiol. 115, 1-13.

Houf, K., Devriese, L.A., De Zutter, L., Van Hoof, J., Vandamme, P., 2001. Development of a new protocol for the isolation and quantification of Arcobacter species from poultry products. Int. J. Food Microbiol. 71, 189-196.

Houf, K., De Zutter, L., Van Hoof, J., Vandamme, P., 2002. Assessment of the genetic diversity among arcobacters isolated from poultry products by using two PCRbased typing methods. Appl. Environ. Microbiol. 68, 2172-2178.

Huws, S.A., Smith, A.W., Enright, M.C., Wood, P.J., Brown, M.R.W., 2006. Amoebae promote persistence of epidemic strains of MRSA. Environ. Microbiol. 8, 1130-1133.

Huws, S.A., Morley, R.J., Jones, M.V., Brown, M.R., Smith, A.W., 2008. Interactions of some common pathogenic bacteria with Acanthamoeba polyphaga. FEMS Microbiol. Lett. $282,258-265$.

Jackson, V., Blair, I., McDowella, D., Kennedy, J., Bolton, D., 2007. The incidence of significant foodborne pathogens in domestic refrigerators. Food Control 16, 6.

Jacob, J., Lior, H., Feuerpfeil, I., 1993. Isolation of Arcobacter butzleri from a drinking water reservoir in Eastern Germany. Zbl. Hyg. Umweltmed. 193, 557-562.

Jeuck, A., Arndt, H., 2013. A short guide to common heterotrophic flagellates of freshwater habitats based on the morphology of living organisms. Protist 164, 842-860.

Jongman, R.H.G., ter Braak, C.J.F., Van Tongeren, O.F.R., 1995. Data analysis in community and landscape ecology. Cambridge University Press, Cambridge, United Kingdom.

Josephson, K.L., Rubino, J.R., Pepper, I.L., 1997. Characterization and quantification of bacterial pathogens and indicator organisms in household kitchens with and without the use of a disinfectant cleaner. J. Appl. Microbiol. 83, 737-750. 
Jung, S.-Y., Matin, A., Kim, K.S., Khan, N.A., 2007. The capsule plays an important role in Escherichia coli K1 interactions with Acanthamoeba. Int. J. Parasitol. 37, 417-423.

Karpov, S.A., Mylnikov, A.P., 1997. Ultrastructure of the colourless flagellate Hyperamoeba flagellata with special reference to the flagellar apparatus. Eur. J. Protistol. 33, 349-355.

King, C.H., Shotts Jr., E.B., Wooley, R.E., Porter, K.G., 1988. Survival of coliforms and bacterial pathogens within protozoa during chlorination. Appl. Environ. Microbiol. 54, 3023-3033.

Koo, O.K., Martin, E.M., Story, R., Lindsay, D., Ricke, S.C., Crandall, P.G., 2013. Comparison of cleaning fabrics for bacterial removal from food-contact surfaces. Food Control 30, 292-297.

Kusumaningrum, H.D., Riboldi, G., Hazeleger, W.C., Beumer, R.R., 2003. Survival of foodborne pathogens on stainless steel surfaces and cross-contamination to foods. Int. J. Food Microbiol. 85, 227-236.

Lambrecht, E., Bare, J., Van Damme, I., Bert, W., Sabbe, K., Houf, K., 2013. Behavior of Yersinia enterocolitica in the presence of the bacterivorous Acanthamoeba castellanii. Appl. Environ. Microbiol. 79, 6407-6413.

Lee, S.Y., 2010. Survival and growth of Escherichia coli on various commercial dish sponge/ dishcloths and inhibitory effect of UV sterilization with or without moderate heat. J. Food Saf. 30, 721-731.

Lee, W.J., Simpson, A.G.B., Patterson, D.J., 2005. Free-living heterotrophic flagellates from freshwater sites in Tasmania (Australia), a field survey. Acta Protozool. 44, 321-350.

Luber, P., 2009. Cross-contamination versus undercooking of poultry meat or eggs which risks need to be managed first? Int. J. Food Microbiol. 134, 21-28.

Macias-Rodriguez, M.E., Navarro-Hidalgo, V., Linares-Morales, J.R., Olea-Rodriguez, M.A., Villarruel-Lopez, A., Castro-Rosas, J., Gomez-Aldapa, C.A., Torres-Vitela, M.R., 2013. Microbiological safety of domestic refrigerators and the dishcloths used to clean them in Guadalajara, Jalisco, Mexico. J. Food Prot. 76, 984-990.

Maeda, H., Akematsu, T., Fukui, R., Matsuoka, T., 2005. Studies on the resting cyst of ciliated protozoan Colpoda cucullus: resistance to temperature and additional inducing factors for en- or excystment. J. Protozool. Res. 15, 7-13.

Mattick, K., Durham, K., Domingue, G., Jorgensen, F., Sen, M., Schaffner, D.W., Humphrey, T., 2003. The survival of foodborne pathogens during domestic washing-up and subsequent transfer onto washing-up sponges, kitchen surfaces and food. Int. J. Food Microbiol. 85, 213-226.

Matz, C., Kjelleberg, S., 2005. Off the hook: how bacteria survive protozoan grazing. Trends Microbiol. 13, 302-307.

Medina, G., Flores-Martin, S., Fonseca, B., Otth, C., Fernandez, H., 2014. Mechanisms associated with phagocytosis of Arcobacter butzleri by Acanthamoeba castellanii. Parasitol. Res. 113, 1933-1942.

Molmeret, M., Horn, M., Wagner, M., Santic, M., Abu Kwaik, Y., 2005. Amoebae as training grounds for intracellular bacterial pathogens. Appl. Environ. Microbiol. 71, 20-28.

Napolitano, J.J., 1982. Isolation of amoebae from edible mushrooms. Appl. Environ. Microbiol. 44, 255-257.

Napolitano, J.J., Collettieggolt, C., 1984. Occurrence of amoebae on oak leaf lettuce (Lactuca sativa var. crispa) and Boston lettuce (Lactuca sativa var. capitata). J. Protozool. 31, 454-455.

Newell, D.G., Koopmans, M., Verhoef, L., Duizer, E., Aidara-Kane, A., Sprong, H., Opsteegh, M., Langelaar, M., Threfall, J., Scheutz, F., van der Giessen, J., Kruse, H., 2010. Food-borne diseases - the challenges of 20 years ago still persist while new ones continue to emerge. Int. J. Food Microbiol. 139, S3-S15.

Niyyati, M., Lorenzo-Morales, J., Rezaie, S., Rahimi, F., Martin-Navarro, C.M., Mohebali, M. Maghsood, A.H., Farnia, S., Valladares, B., Rezaeian, M., 2010. First report of a mixed infection due to Acanthamoeba genotype T3 and Vahlkampfia in a cosmetic soft contact lens wearer in Iran. Exp. Parasitol. 126, 89-90.

Nocker, A., Burr, M., Camper, A.K., 2007. Genotypic microbial community profiling: a critical technical review. Microb. Ecol. 54, 276-289.

Page, F.C., 1988. A New Key to Freshwater and Soil Gymnamoebae. Freshwater Biological Association, Ambleside, United Kingdom.

Patterson, D.J., 1998. Free-living Freshwater Protozoa: A Colour Guide. Manson Publishing Ltd., London.

Pernthaler, J., 2005. Predation on prokaryotes in the water column and its ecological implications. Nat. Rev. Microbiol. 3, 537.

Pickup, Z.L., Pickup, R., Parry, J.D., 2007. Growth of Acanthamoeba castellanii and Hartmannella vermiformis on live, heat-killed and DTAF-stained bacterial prey. FEMS Microbiol. Ecol. 61, 264-272.

Rønn, R., Ekelund, F., Christensen, S., 1995. Optimizing soil extract and broth media for MPN-enumeration of naked amoebas and heterotrophic flagellates in soil. Pedobiologia 39, 10-19.

Rude, R.A., Jackson, G.J., Bier, J.W., Sawyer, T.K., Risty, N.G., 1984. Survey of fresh vegetables for nematodes, amoebae, and Salmonella. J. Assoc. Off. Anal. Chem. 67, 613-615.

Schuppler, M., 2014. How the interaction of Listeria monocytogenes and Acanthamoeba spp. affects growth and distribution of the food borne pathogen. Appl. Microbiol. Biotechnol. 98, 2907-2916.
Scott, E., Duty, S., Callahan, M., 2008. A pilot study to isolate Staphylococcus aureus and methicillin-resistant $S$. aureus from environmental surfaces in the home. Am. J. Infect. Control 36, 458-460.

Sharma, A.K., Pandey, R., Pandey, K., 2004. A report on the occurrence of amphizoic amoebae from carrot. Flora Fauna (Jhansi) 10, 141-143.

Sharma, M., Eastridge, J., Mudd, C., 2009. Effective household disinfection methods of kitchen sponges. Food Control 20, 310-313.

Sherr, E.B., Sherr, B.F., 2002. Significance of predation by Protists in aquatic microbial food webs. Anton. Leeuw. Int. J. Gen. Mol. Microbiol. 81, 293-308.

Siemersma, F.J., 1989. De Nederlandse naaktamoeben (Rhizopoda, Gymnamoebia) + bijlage platen $1 \mathrm{t} / \mathrm{m}$ 52. Rob Kok Old Books \& Prints, Loosdrecht, UT, Netherlands.

Smirnov, A.V., Brown, S., 2004. Guide to the methods of study and identification of soil gymnamoebae. Protistology 3, 148190.

Smirnov, A.V., Goodkov, A.V., 1999. An Illustrated list of basic morphotypes of Gymnamoebia (Rhizopoda, Lobosea). Protistology 1, 20-29.

Snelling, W.J., McKenna, J.P., Lecky, D.M., Dooley, J.S., 2005. Survival of Campylobacter jejuni in waterborne protozoa. Appl. Environ. Microbiol. 71, 5560-5571.

Snelling, W.J., Stern, N.J., Lowery, C.J., Moore, J.E., Gibbons, E., Baker, C., Dooley, J.S., 2008. Colonization of broilers by Campylobacter jejuni internalized within Acanthamoeba castellanii. Arch. Microbiol. 189, 175-179.

Sriram, R., Shoff, M., Booton, G., Fuerst, P., Visvesvara, G.S., 2008. Survival of Acanthamoeba cysts after desiccation for more than 20 years. J. Clin. Microbiol. 46, 4045-4048.

ter Braak, C.J.F., Smilauer, P., 1998. Canoco Reference Manual and User's Guide to Canoco for Windows: Software for Canonical Community Ordination (version 4). Microcomputer Power, Ithaca, NY.

StataCorp., 2011. Stata Statistical Software: Release 12. College Station, TX: StataCorp LP.

Tezcan-Merdol, D., Ljungstrom, M., Winiecka-Krusnell, J., Linder, E., Engstrand, L., Rhen, M., 2004. Uptake and replication of Salmonella enterica in Acanthamoeba rhysodes. Appl. Environ. Microbiol. 70, 3706-3714.

Thomas, V., McDonnell, G., Denyer, S.P., Maillard, J.Y., 2010. Free-living amoebae and their intracellular pathogenic microorganisms: risks for water quality. FEMS Microbiol Rev. 34, 231-259.

Vaerewijck, M.J.M., Sabbe, K., Baré, J., Houf, K., 2008. Microscopic and molecular studies of the diversity of free-living protozoa in meat-cutting plants. Appl. Environ. Microbiol. 74, 5741-5749.

Vaerewijck, M.J.M., Sabbe, K., Van Hende, J., Baré, J., Houf, K., 2010. Sampling strategy, occurrence and diversity of free-living protozoa in domestic refrigerators. J. Appl. Microbiol. 109, 1566-1578.

Vaerewijck, M.J.M., Sabbe, K., Baré, J., Houf, K., 2011. Occurrence and diversity of free-living protozoa on butterhead lettuce. Int. J. Food Microbiol. 147, 105-111.

Vaerewijck, M.J.M., Sabbe, K., Bare, J., Spengler, H.P., Favoreel, H.W., Houf, K., 2012 Assessment of the efficacy of benzalkonium chloride and sodium hypochlorite against Acanthamoeba polyphaga and Tetrahymena spp. J. Food Prot. 75, $541-546$

Vaerewijck, M.J.M., Baré, J., Lambrecht, E., Sabbe, K., Houf, K., 2014. Interactions of foodborne pathogens with free-living protozoa: potential consequences for food safety. Compr. Rev. Food Sci. Food Saf. 13, 924-944.

Van den Abeele, A.M., Vogelaers, D., Van Hende, J., Houf, K., 2014. Prevalence of Arcobacter species among humans, 2008-2013, Belgium, Emerg. Infect. Dis. http://dx.doi.org/10 3201/eid2010.140433.

Van Driessche, E., Houf, K., 2007. Discrepancy between the occurrence of Arcobacter in chickens and broiler carcass contamination. Poult. Sci. 86, 744-751.

Visvesvara, G.S., Schuster, F.L., 2008a. Opportunistic free-living amoebae, part I. Clin. Microbiol. Newsl. 30, 158.

Visvesvara, G.S., Schuster, F.L., 2008b. Opportunistic free-living amoebae, part II. Clin. Microbiol. Newsl. 30, 166.

Walker, G., Silberman, J.D., Karpov, S.A., Preisfeld, A., Foster, P., Frolov, A.O., Novozhilov, Y., Sogin, M.L., 2003. An ultrastructural and molecular study of Hyperamoeba dachnaya, n. sp., and its relationship to the mycetozoan slime moulds. Eur. J. Protistol. 39, 319-336.

Walochnik, J., Picher, O., Aspock, C., Ullmann, M., Sommer, R., Aspock, H., 1998 Interactions of "Limax amoebae" and Gram-negative bacteria: experimental studies and review of current problems. Tokai J. Exp. Clin. Med. 23, 273-278.

Walochnik, J., Michel, R., Aspock, H., 2004. A molecular biological approach to the phylogenetic position of the genus Hyperamoeba. J. Eukaryot. Microbiol. 51, 433-440.

Wu, V.C.H., Jitareerat, P., Fung, D.Y.C., 2003. Comparison of the pulsifier and the stomacher for recovering microorganisms in vegetables. J. Rapid Methods Autom. Microbiol. 11, $145-152$.

Zaman, V., Zaki, M., Howe, J., Ng, M., Leipe, D.D., Sogin, M.L., Silberman, J.D., 1999. Hyperamoeba isolated from human feces: description and phylogenetic affinity. Eur. J. Protistol. 35, 197-207.

Zhou, X., Elmose, J., Call, D.R., 2007. Interactions between the environmental pathogen Listeria monocytogenes and a free-living protozoan (Acanthamoeba castellanii). Environ. Microbiol. 9, 913-922. 